\title{
Plant remains from the Kreftenheye Formation (Eemian) at Raalte, The Netherlands
}

\author{
Raymond W. J. M. van der Ham • Wim J. Kuijper • \\ M. Joop H. Kortselius · Johan van der Burgh • \\ Graham N. Stone · Jan G. Brewer
}

Received: 3 May 2006/Accepted: 15 November 2006/Published online: 19 June 2007

(C) Springer-Verlag 2007

\begin{abstract}
The Kreftenheye Formation is a fluviatile deposit occurring in the central part of the Netherlands. The present study deals with the plant remains found in suctiondredged bulk samples from its largely Eemian Zutphen Member, a clayey sediment formerly known as the claypeat bed or the Salvinia bed. It reports the discovery of a large number of galls induced by the asexual generation of the currently southeast European oak gall wasp Andricus hungaricus. The associated plant remains include seeds, fruits, conifer cones, wood, spines, leaf fragments, buds, bud scales, stem fragments, bryophytes, sporangia, oospores, palynomorphs, galls, jet and amber. The palynomorph samples indicate the Late Eemian pollen zone E5b of the Carpinus phase as the origin of the galls, but the other macrofossils may have a wider stratigraphic range, including possibly also material from (a part) of the zones E3-E5a. Several elements, such as Celtis, Chamaecyparis, Juglans, Magnolia and Pterocarya, date almost certainly
\end{abstract}

R. W. J. M. van der Ham $(\bowtie)$ - M. J. H. Kortselius Nationaal Herbarium Nederland, Universiteit Leiden, P.O. Box 9514, 2300 RA Leiden, The Netherlands

e-mail: ham@nhn.leidenuniv.nl

W. J. Kuijper

Faculteit der Archeologie, Universiteit Leiden,

P.O. Box 9515, 2300 RA Leiden, The Netherlands

J. van der Burgh

Laboratory of Palaeobotany and Palynology,

Budapestlaan 4, 3584 CD Utrecht, The Netherlands

G. N. Stone

Institute of Evolutionary Biology, West Mains Road,

Edinburgh EH9 3JT, UK

J. G. Brewer

Hogebroeksweg 32, 8102 RK Raalte, The Netherlands from earlier interglacials. The list of plant remains is dominated by fresh water plants, riparian elements and ancient woodland taxa, which reflects the ecological range of the IJssel valley and adjacent ice-pushed ridges very well. Thermophilous elements include Brasenia schreberi, Buxus sempervirens, Cornus mas, Najas minor, Salvinia natans, Trapa natans and possibly also Andricus hungaricus. Quercus cerris, the probable host of the sexual generation of A. hungaricus was not found.

Keywords Eemian - Interglacial flora - Oak galls · Andricus hungaricus · Carpinus $\cdot$ Salvinia $\cdot$ Trapa

\section{Introduction}

The Eemian (Ipswichian, in the British Isles) belongs to the warmest stages of the Dutch Pleistocene (Zagwijn 1975, 1996). It is at the base of marine isotope stage (MIS) 5 , but might not correspond completely with the basal substage 5e (Shackleton et al. 2003). Depending on the interpretation of the results of diverse stratigraphical studies, the Eemian lasted very roughly between 10,000 and 22,000 years. De Mulder et al. (2003) set the beginning and the end of the Eemian at 130,000 and 115,000 years ago, respectively.

Due to the worldwide melting of ice, the sea level was relatively high in the Eemian, which resulted in The Netherlands in extensive marine sedimentation (Eem Formation) in the coastal areas and in deep glacial basins left by the Saalian ice sheet. Fluviatile sediments filled up the river valleys of the Maas (Beegden Formation) and the Rhine (Kreftenheye Formation). For a long time the Eemian sediments were known as mainly marine deposits with a rich mollusc fauna (Bosch et al. 2000). Burck (1949) 
was the first to demonstrate the presence of a more or less continuous terrestrial bed (continentale Eemlagen) in the coarse sands of the Kreftenheye Formation in the present valley of the river IJssel, which in the Eemian was occupied by the Rhine and bordered by high ice-pushed ridges. Because of the occurrence of land and marsh plants, and molluscs such as Planorbis and Valvata, Burck designated the terrestrial bed as a fresh water deposit, which he named the klei-veen laag (clay-peat bed), or Salvinia-laag (Salvinia bed) if spores of the water fern Salvinia were well represented.

Palaeobotanical research into the Dutch Eemian started rather late (Van der Vlerk and Florschütz 1950; Bosch et al. 2000). Florschütz (1930) reported the first plant macrofossils (Aldrovanda, Ceratophyllum, Salvinia) from Eefde. Salvinia was found in several other localities near Zutphen and also in Deventer (Burck 1949). The first data of Eemian forests were provided in pollen sequences from Hengelo (Florschütz 1934), the Eem valley and Wieringermeerpolder (Vermeer-Louman 1934). Florschütz (1935) and Van der Vlerk and Florschütz (1950) described material from Zwartewater near Zwolle (pollen) and Noordoostpolder (pollen and macrofossils, for example Aldrovanda, Brasenia, Salvinia). Pollen sequences from the Peel area were published by Eshuis (1946) and Florschütz and Anker-van Someren (1956), and the pollen data from Amersfoort, Farmssum and Moershoofd are well known (Zagwijn 1961). Further contributions are those by Van Geel et al. (1986, 1995; pollen, fungal spores and macrofossils), Van Leeuwen et al. (2000; pollen) and Cleveringa et al. (2000; pollen). The data from the localities near Deventer, Zutphen and Zwolle were mentioned by Burck (1949) as palaeobotanical evidence for his Eemian clay-peat bed.

For decades the fluviatile gravel and sand deposits of the Kreftenheye Formation in the IJssel valley have been extracted by suction-dredging, which brought many animal bones to the surface. Beside many later, Weichselian species, typical Eemian elements such as a Hippopotamus incognitus (hippo) and Palaeoloxodon antiquus (straighttusked elephant) were reported (Kerkhoff 1993; Mol 1993, 1994; Mol et al. 1999; Van den Hoek Ostende et al. 2002; Van Uum 2003). Plant remains, mainly wood, are common too (Stapert 1985; Van Uum 2003).

Since ca. 1997, the Kreftenheye Formation has been exploited in the Hooge Broek suction-dredging pit near Raalte, in the northeastern part of the IJssel valley, which yielded a large variety of animal bones, including Hippopotamus incognitus and Palaeoloxodon antiquus (Bosscha Erdbrink et al. 2001; Bosscha Erdbrink 2002, 2003). Bosscha Erdbrink et al. (2001) also mentioned plant remains: "many pieces of different kinds of wood and fructifications (such as horse chestnuts, pine and fir-cones), but also pieces of heather and twigs of diverse herbs". The identification of the 'horse chestnuts' as well-preserved galls of Andricus hungaricus, a southeast European oak gall wasp (G. N. Stone et al., in preparation) resulted in an intensive search for associated fossils. The clay from which the galls originated appeared to be very rich in plant remains, and gradually it became clear that it represented Burck's clay-peat bed, which is the Zutphen Member of the Kreftenheye Formation in the new lithostratigraphical subdivision of The Netherlands (De Mulder et al. 2003). As such, it offered an excellent opportunity to gain more insight into the vegetation of the Eemian IJssel valley area, including the environment of Andricus hungaricus.

\section{Materials and methods}

The materials studied are diverse, consisting of seeds and fruits, conifer cones, wood, spines, leaf fragments, buds, bud scales, stem fragments of herbaceous plants, leafy stems and branch fragments of bryophytes, sporangia (Salvinia), oospores (Chara, Nitella/Tolypella), palynomorphs, galls, jet and amber. Further remains of animals, mainly fresh water molluscs, were found. All materials were collected from the waste heaps of the Hooge Broek sand/gravel pit $\left(52^{\circ} 25^{\prime} 20^{\prime \prime} \mathrm{N}, 6^{\circ} 18^{\prime} 30^{\prime \prime} \mathrm{E}\right)$ near Raalte (Fig. 1), The Netherlands, which is exploited by REKO Grondverzet en Wegenbouw bedrijf Raalte B.V. through suction-dredging down to ca. $30 \mathrm{~m}$. In purifying the sand and gravel, the waste is washed out in diverse fractions at different places in the process. Plant remains occur in four of them. Fraction 1 (Fig. 2a) contains the coarsest material, such as stones, clay, bones and wood. In this fraction the conifer cones, oak galls (37-57 $\mathrm{mm}$ diameter) and the single walnut were also found. Most plant remains were

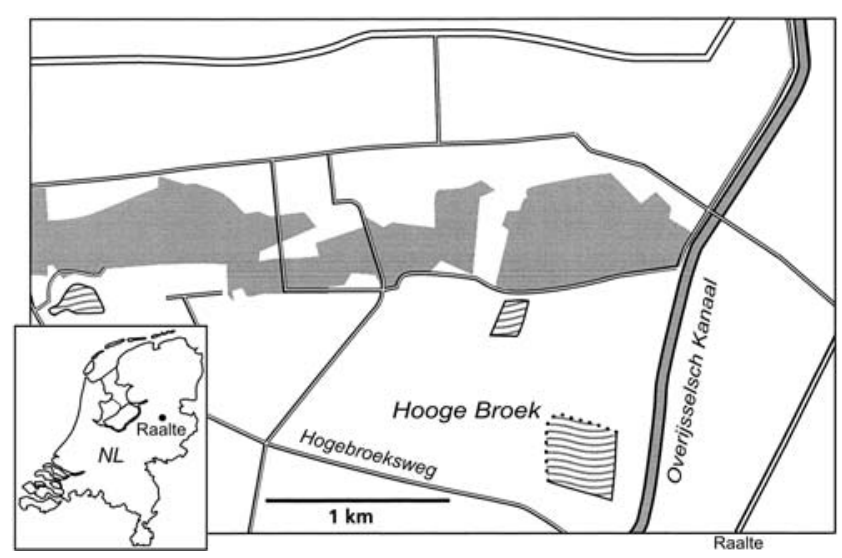

Fig. 1 Map showing the geographical position of the Hooge Broek sand/gravel pit $\left(52^{\circ} 25^{\prime} 20^{\prime \prime} \mathrm{N}, 6^{\circ} 18^{\prime} 30^{\prime \prime} \mathrm{E}\right)$ near Raalte, The Netherlands 
Fig. 2 Hooge Broek sand/ gravel pit of the REKO Grondverzet en Wegenbouw bedrijf Raalte B.V. on 21 October 2004. a Part of the pit, showing the suction dredger in the background at the left and the waste heap with fraction 1 material in the foreground at the right; b Waste heap with fraction 2 material; c Detail of waste heap with fraction 2 material, showing a large quantity of wood; $\mathbf{d}$ Waste heap with fraction 3 material being sorted out in the process of purifying the sand and gravel
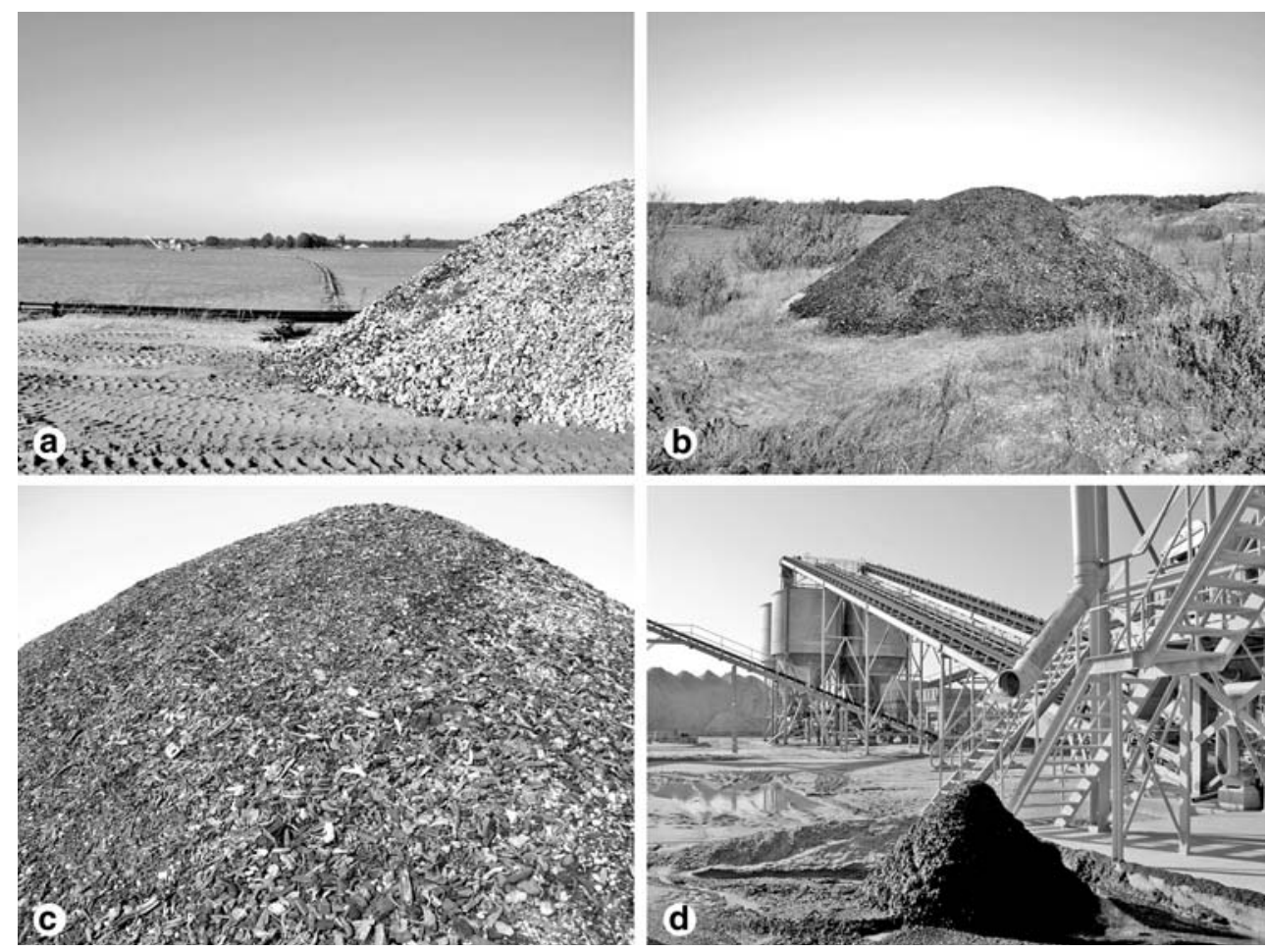

collected from samples of fractions 2, 3 and 4. Fractions 3 and 4 consisted almost exclusively of plant remains. Fraction 2 (ca. $75 \mathrm{~kg}$; objects up to ca. $3 \mathrm{~cm}$ diameter; Fig. $2 \mathrm{~b}, \mathrm{c})$ and fraction 3 (3 kg; objects up to ca. $5 \mathrm{~mm}$ diameter; Fig. 2d) were sampled wet and picked out dry. Fraction 4 (100 g; objects up to ca. $2 \mathrm{~mm}$ diameter) was sampled wet and picked out wet.

Two samples from the supposed clay-peat bed (Salvinia bed) were analysed for palynomorphs. One sample $\left(0.5 \mathrm{~cm}^{3}\right)$ consisted of the clay adhering to one of the oak galls, and the other $\left(1 \mathrm{~cm}^{3}\right)$ was taken from the centre of a large piece of similar clay from fraction 1 . Both samples were washed for macrofossils. For scanning electron micrographs the latter sample, as well as the supernatant of a washed piece of clay from fraction 2, was sputter-coated with gold and examined with a JSM 5300 scanning electron microscope.

Table 1 lists all items found loose on the heaps of fractions 1 and 2, including the wood, galls, cones, and some fruit remains, amber and jet. In Table 2 all plant macrofossils from the samples of fractions 2, 3 and 4 are given, except for the bryophytes, which are listed in Table 3 . Table 4 presents the results of the analyses. Because the fractions 2, 3 and 4 were sampled independently, the numbers of the objects listed are related to each other only within the samples. The plant names are according to Touw and Rubers (1989) and Smith (2004) for the bryophytes, and to Van der Meijden (2005) for the vascular plants. The material has been added to the collections of the Laboratorium voor Palaeobotanie en Palynologie, Utrecht, The Netherlands (wood) and the Nationaal Natuurhistorisch Museum Naturalis, Leiden, The Netherlands (other material).

One of the oak galls was conventionally radiocarbon dated (GrN-29594: $>38,500$ в.P.).

\section{Stratigraphy}

Stratigraphical data for the Hooge Broek area come from a boring $1 \mathrm{~km}$ southeast of the pit. The lithological in-formation from this boring (NITG B27F0051) is available via the internet website (http://www.dinoloket.nl) of the Netherlands Institute of Applied Geoscience (TNO-NITG) and was interpreted by W.E. Westerhoff (personal communication). The boring $(0-33 \mathrm{~m})$ shows the following lithological units (see also De Mulder et al. 2003):

0-3 m: Boxtel Formation, Wierden Member (coversand); mainly moderately to very fine sand

3-5 m: Boxtel Formation, unspecified, probably fluvio-periglacial deposit; mainly moderately coarse sand

5-12.5 m: Kreftenheye Formation, unspecified fluviatile deposit; mainly moderately to very coarse sand

12.5-14 m: Kreftenheye Formation, Zutphen Member (fluviatile deposit); mainly clay

14-31 m: Kreftenheye Formation, unspecified fluviatile deposit; mainly moderately to very coarse sand 
Table 1 Plant remains from the Kreftenheye Formation at Raalte (Eemian, The Netherlands)

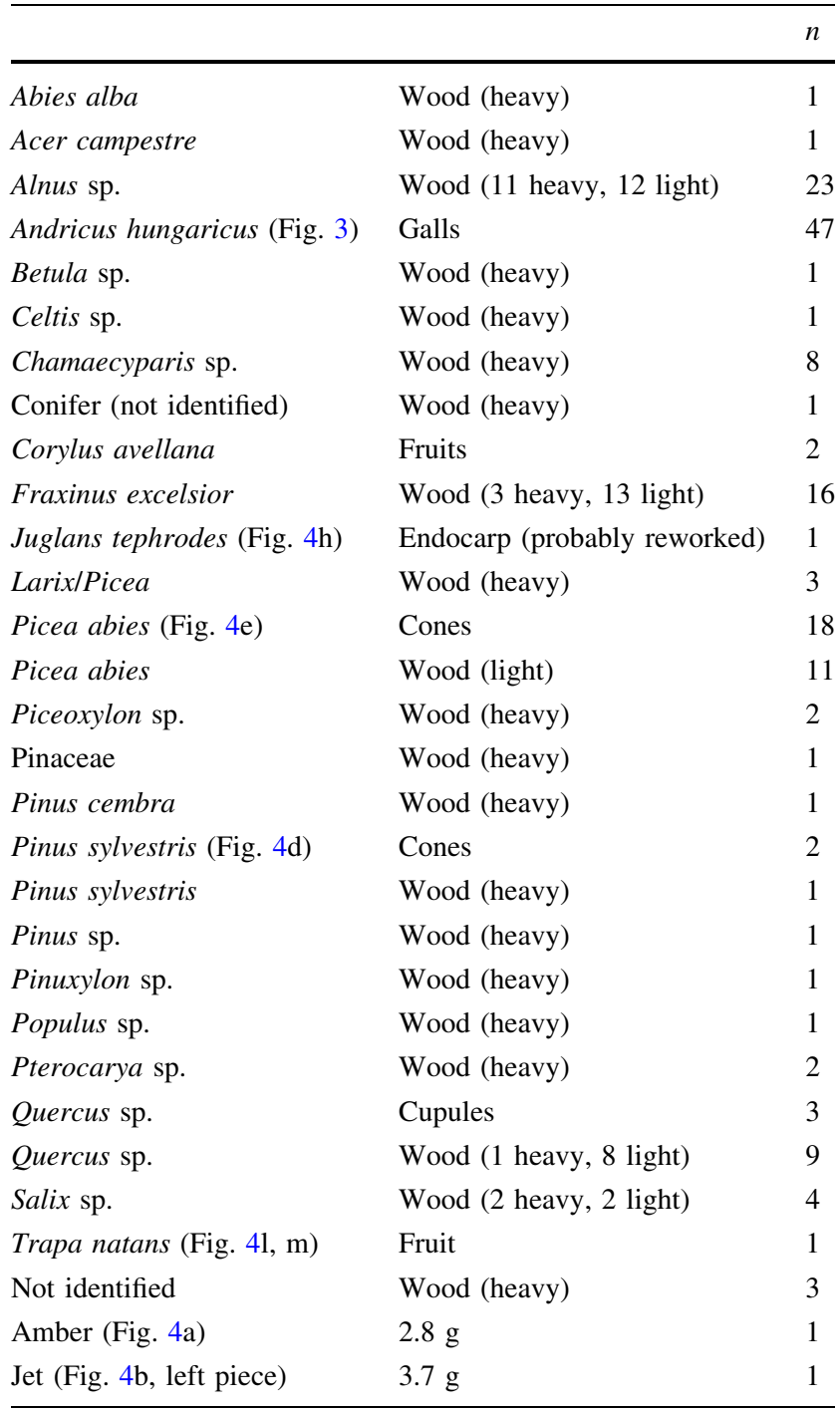

Loose items from fractions 1 and 2: cones, fruits, galls, wood (heavy/ light: see text), amber and jet

31-33 m: Kreftenheye Formation, Twello Member (fluviatile-deltaic material deposited by the Rhine after retreat of the ice sheet of the penultimate glacial); mainly clay

Within this sequence the Twello Member and the Zutphen Member are clayey strata. The Twello Member is between 15 and $30 \mathrm{~m}$ thick in the Hooge Broek area, which means that the glacial surface is at least $12 \mathrm{~m}$ below the base of the boring. It thins out rapidly towards the easterly ice-pushed ridge (Lemelerberg-Hellendoornsche Berg) at about $6 \mathrm{~km}$ distance, while it is more than $100 \mathrm{~m}$ thick in the centre of the basin to the west (see also De Jong 1955).

The Zutphen Member consists of sandy to slightly silty clay, with moderately fine sand and locally with peat beds, embedded in the moderately to very coarse sands with gravel of the rest of the Kreftenheye Formation. It was deposited by the meandering Eemian Rhine in the valley of the present river IJssel. It is the only clay bed above the Twello Member in the Hooge Broek area and is considered identical with Burck's clay-peat bed (Salvinia bed). Burck (1949) described this bed as a more or less continuous, up to $17 \mathrm{~m}$ (averaging 3.5) thick fresh water deposit occurring throughout the IJssel valley.

Our plant remains were not directly sampled from the Zutphen Member, but most probably they do originate from it, because this is the only bed in the Hooge Broek area known to contain such material. In our view they were washed from this clay bed in the process of sorting and purifying the sand and gravel (Fig. 2d). Washing pieces of the grey clay found together with the plant remains and adhering to many objects yielded similar plant remains as those found loose in the samples, such as many mega- and microsporangia of Salvinia (see Table 2). This clay contains a distinctly Late Eemian pollen assemblage (see below), which corresponds very well with the macrofossil assemblage, but does not fit the Early Eemian fluvio-deltaic environment in which the Twello clay was deposited. Moreover, the top of the thick Twello clay bed is the lower limit for the suction-dredger at Hooge Broek, so that probably only small amounts of Twello clay would have entered the process. We were able to check some samples from a boring at the Hooge Broek pit kept by the REKO company. The sample from the 12-14.4 m interval (probably Zutphen clay), which consisted of the same grey clay as found associated with our plant remains, yielded abundant Salvinia sporangia. The sample from the 14.4-17 m interval (Zutphen clay?) was more sandy and contained only sparse Salvinia sporangia, while the samples from the 31-36 $\mathrm{m}$ and 36-40 $\mathrm{m}$ intervals (both probably Twello clay) showed no Salvinia sporangia.

Yet, some of the species recorded probably predate the Eemian, because their known last occurrences in Europe are from earlier interglacials, for example Pterocarya from the Holsteinian (ca. 410,000-370,000 years ago), Juglans from the Waalian (ca. 1.5-1.2 million years ago), Magnolia from the Tiglian (ca. 2.45-1.8 million years ago) and Stratiotes kaltennordheimensis from the Miocene (ca. 235.3 million years ago) (see below). These elements are interpreted as being reworked from nearby ice-pushed areas-in which among others, the Holsteinian (Urk Formation) is represented-and embedded in the Eemian context of the Hooge Broek area.

Our material does not offer the sequential information and stratigraphical accuracy that might be extracted from a core, but, due to the large volumes of clay washed in the process, it provides a very rich spectrum of Eemian plant remains, quantitatively as well as qualitatively. The 
Table 2 Plant remains from the Kreftenheye Formation at Raalte (Eemian, The Netherlands)

\begin{tabular}{|c|c|c|c|c|}
\hline Fraction & & $2(n)$ & $3(n)$ & $4(n)$ \\
\hline Abies alba & Leaf fragments & - & 2 & 13 \\
\hline Acer sp. (spp.?) (Fig. 5a) & Without wing & 73 & 88 & 1 \\
\hline cf. Aethusa cynapium & & - & 1 & - \\
\hline Ajuga cf. genevensis (Fig. 6a) & & - & 1 & - \\
\hline Ajuga reptans & & - & - & 1 \\
\hline Alisma sp. & & - & - & 40 \\
\hline Alnus sp.* (Fig. 5b) & Cones & 322 & 145 & 1 \\
\hline Alnus sp. & & 4 & 24 & 111 \\
\hline Betula sp. & Without wing & - & - & 6 \\
\hline Bidens сегпиа & & - & 2 & - \\
\hline Bidens tripartita & & - & 2 & - \\
\hline Brasenia schreberi & & 8 & - & - \\
\hline Buxus sempervirens (Fig. $5 \mathrm{~m}$ ) & Leaf fragments & 5 & 39 & 13 \\
\hline Carex hirta type & & - & 7 & - \\
\hline Carex pseudocyperus & Several with utricle & - & - & 8 \\
\hline Carex spp. (ca. 7) & Several with utricle & - & 32 & 48 \\
\hline Carpinus betulus (Fig. 5c) & Complete/fragments & $24 / 6$ & $287 / 180$ & -14 \\
\hline Caryophyllaceae & $2.5 \mathrm{~mm}$, black & - & 1 & - \\
\hline Ceratophyllum demersum & & 13 & 15 & - \\
\hline Ceratophyllum sp. & & 2 & 9 & 2 \\
\hline cf. Chara sp. & Oospore & - & - & 1 \\
\hline Chenopodium polyspermum & & - & - & 2 \\
\hline Chenopodium rubrum & $0.5 \mathrm{~mm}$ & - & - & 1 \\
\hline Cirsium sp. & $3.0 \times 1.1-1.3 \mathrm{~mm}$ & - & - & 4 \\
\hline Clematis vitalba (Fig. 5d) & & 1 & 20 & 6 \\
\hline Cornus mas (Fig. 5g, h) & & 4 & 7 & - \\
\hline Cornus sanguinea (Fig. 5i) & & 16 & 39 & - \\
\hline Corylus avellana (Fig. 4i) & Complete/fragments & $7 / 45$ & -14 & - \\
\hline Crataegus monogyna & & 2 & - & - \\
\hline Cyperus fuscus & $0.8 \times 0.5 \mathrm{~mm}$ & - & - & 2 \\
\hline Echinochloa crus-galli (Fig. 6b) & & - & - & 1 \\
\hline Eleocharis palustris & & - & - & 1 \\
\hline Eupatorium cannabinum & & - & - & 1 \\
\hline Euphorbia palustris & & 1 & - & - \\
\hline Galium sp. & With hexagonal cells & - & - & 1 \\
\hline cf. Heracleum sphondylium & & - & 1 & - \\
\hline Hippuris vulgaris & & - & 5 & 4 \\
\hline Humulus lupulus & & - & - & 1 \\
\hline Hydrocharis morsus-ranae & & - & - & 12 \\
\hline Hypericum sp. & Finely reticulate & - & - & 1 \\
\hline Ilex aquifolium (Fig. 5e) & & 2 & 26 & - \\
\hline Iris pseudacorus & & 18 & 2 & - \\
\hline Juncus sp. & & - & - & 1 \\
\hline Lamiaceae & & - & - & 4 \\
\hline Lamium sp. & $2.7 \times 1.6 \mathrm{~mm}$ & - & 1 & - \\
\hline Larix/Picea/Pinus & Wing fragment & - & - & 1 \\
\hline Lemna sp. & & - & - & 2 \\
\hline Lycopus europaeus & & - & - & 7 \\
\hline
\end{tabular}


Table 2 continued

\begin{tabular}{|c|c|c|c|c|}
\hline Fraction & & $2(n)$ & $3(n)$ & $4(n)$ \\
\hline Lythrum salicaria* & & - & - & 4 \\
\hline Magnolia cor (Fig. 4g) & Probably reworked & 2 & - & - \\
\hline Mentha aquatica/arvensis & & - & - & 14 \\
\hline Menyanthus trifoliata & & 1 & - & - \\
\hline Najas flexilis & & - & - & 1 \\
\hline Najas marina & & 1 & 11 & - \\
\hline Najas minor & & - & - & 2 \\
\hline Nitella/Tolypella sp.* & Oospores & - & - & 6 \\
\hline Nuphar lutea* & & 36 & 98 & 3 \\
\hline Nymphaea alba & & 1 & 16 & 7 \\
\hline Nymphoides peltata & & 1 & 2 & - \\
\hline Oenanthe aquatica & & 1 & 23 & 62 \\
\hline Persicaria hydropiper & $3.6 \times 2.1 \mathrm{~mm}$ & - & 1 & 1 \\
\hline Persicaria lapathifolia* & Several with perianth & - & 2 & 21 \\
\hline Persicaria minor & & - & 1 & - \\
\hline Phragmites australis* & & - & - & 10 \\
\hline Physalis alkekengi & & - & - & 2 \\
\hline Picea abies & Cone/leaf fragments & $12 /-$ & $-/ 1$ & $-/ 2$ \\
\hline Picea sp. & Cones/cone scales & $14 / 18$ & - & - \\
\hline Pinus sp. & Cone & 1 & - & - \\
\hline Plantago major & & - & - & 1 \\
\hline Poaceae & Stem fragments & ca. 400 & 74 & - \\
\hline Populus sp. & Bud scales & - & 31 & - \\
\hline Potamogeton spp. & & 16 & 42 & 15 \\
\hline Potentilla sp. & $1 \mathrm{~mm}$ & - & - & 1 \\
\hline Prunus cf. spinosa & & 4 & - & - \\
\hline Quercus sp. (Fig. 4j) & Mostly cupules & 58 & 2 & - \\
\hline Quercus sp. & Leaf fragments & 9 & - & - \\
\hline Quercus? & Buds & 6 & 2 & - \\
\hline Quercus? & Bud scales & 1 & 75 & 1 \\
\hline Ranunculus acris & $2.7 \times 1.8 \mathrm{~mm}$ & - & - & 1 \\
\hline Ranunculus cf. acris & & - & 1 & - \\
\hline Ranunculus aquatilis type* & & - & 2 & 11 \\
\hline Ranunculus flammula & & - & - & 2 \\
\hline Ranunculus repens type & & - & 6 & 3 \\
\hline Ranunculus sceleratus & & - & - & 3 \\
\hline Rhamnus frangula (Fig. 5f) & & - & 7 & - \\
\hline Rosaceae? & & - & 1 & - \\
\hline Rubus caesius & $3.9 \times 2.4 \mathrm{~mm}$ & - & - & 1 \\
\hline Rubus fruticosus & & 2 & 61 & 24 \\
\hline Rubus? & Spines & 3 & 29 & 15 \\
\hline Rumex maritimus (Fig. 5j) & & - & 1 & 1 \\
\hline Rumex maritimus & Perianth fragments & 47 & 185 & 26 \\
\hline Rumex sp. & & - & 2 & - \\
\hline Rumex sp. & Perianth fragments & 3 & - & - \\
\hline Sagittaria sagittifolia & & - & - & 13 \\
\hline Salix sp. & Fruits & - & - & 7 \\
\hline Salix sp. & Bud scales & - & 22 & 2 \\
\hline
\end{tabular}


Table 2 continued

\begin{tabular}{|c|c|c|c|c|}
\hline Fraction & & $2(n)$ & $3(n)$ & $4(n)$ \\
\hline Salvinia natans* (Fig. 8j-m) & Mega/microsporangia & Abundant in clay & Abundant in clay & Abundant \\
\hline Sambucus sp. (not S. ebulus) & Complete/fragments & - & $11 / 4$ & $2 / 4$ \\
\hline Schoenoplectus lacustris* (Fig. 5k) & Several with perianth & 26 & 478 & 145 \\
\hline Scrophularia sp. & & - & - & 2 \\
\hline Silene sp. & $1.0 \mathrm{~mm}$, with warts & - & - & 1 \\
\hline Solanum dulcamara & & - & 5 & 16 \\
\hline Sonchus asper & & - & - & 2 \\
\hline Sparganium emersum/natans & ca. $2.5 \mathrm{~mm}$ & 2 & 6 & - \\
\hline Sparganium erectum & & 4 & 13 & 3 \\
\hline Stachys arvensis/sylvatica & Complete/fragments & - & 9/- & $7 / 5$ \\
\hline Stachys cf. palustris & & 2 & 9 & - \\
\hline Staphylea pinnata (Fig. 5n) & & 4 & - & - \\
\hline Stellaria cf. media & & - & - & 1 \\
\hline Stellaria sp. 1 & $0.9 \mathrm{~mm}$, small spines & - & - & 1 \\
\hline Stellaria sp. 2 & $1.7 \mathrm{~mm}$, big spines & - & - & 1 \\
\hline Stratiotes aloides (Fig. 51) & & 10 & 25 & 2 fr. \\
\hline Stratiotes aloides & Leaf margin teeth & - & - & 2 \\
\hline S. kaltennordheimensis (Fig. 4f) & Probably reworked & 20 & 1 & - \\
\hline Taxus baccata & & 1 & - & - \\
\hline Taxus baccata & Leaf fragments & - & 6 & 1 \\
\hline Tilia platyphyllos & & 1 & 8 & - \\
\hline Tilia $\mathrm{sp}$. & & - & 5 & 3 \\
\hline Trapa natans (Fig. $4 \mathrm{n}-\mathrm{q}$ ) & \pm Complete/fragments & $52 / 293$ & $-/ 10$ & - \\
\hline Typha sp. & & - & - & 7 \\
\hline Urtica dioica & & - & - & 66 \\
\hline Urtica urens* & & - & - & 49 \\
\hline Valeriana dioica & & - & - & 1 \\
\hline Veronica beccabunga type & $0.6 \times 0.45 \mathrm{~mm}$ & - & - & 1 \\
\hline Viola sp. & & - & 8 & 6 \\
\hline Vitis sylvestris (Fig. 5o) & & - & 1 & - \\
\hline Xanthium cf. strumarium (Fig. 5p) & & 1 & 1 & - \\
\hline Zannichellia palustris & & - & - & 12 \\
\hline Unidentified & & Several & Many & Several \\
\hline Amber & $0.4 \mathrm{~g}$ & 1 & - & - \\
\hline Jet (Fig. 4b, right piece, 4c) & & Abundant & Abundant & Present \\
\hline Unidentified galls (Fig. 4k) & & 2 & - & - \\
\hline
\end{tabular}

Samples from fractions 2, 3 and 4 (excluding mosses; * also in clay of palynological samples). Unless specified otherwise, the remains are fruit and/or seed fragments

radiocarbon-dated oak gall is older than 38,500 в.P., which excludes a Holocene origin.

\section{Plant remains}

Galls

Almost all galls described here were found in fraction 1 (Table 1). They are preserved as slightly to moderately compressed (originally approximately spherical), thickwalled, hollow structures ranging in diameter between 37 and $57 \mathrm{~mm}(n=47)$. Their exterior is marked with regularly spaced bumps (Fig. 3a). The airspace contains a fragile, thin-walled larval chamber of 5-6 mm (Fig. 3b, c). Evidently, the specimens represent a single species, which is identifiable as an oak cynipid gall. In the Cynipidae, gall structure is an excellent guide to identity of the gallinducer (Stone and Cook 1998). The large size of our galls and the presence of an internal airspace around a separate 
Table 3 Plant remains from the Kreftenheye Formation at Raalte (Eemian, The Netherlands)

\begin{tabular}{|c|c|c|}
\hline & $n$ & Length $(\mathrm{cm})$ \\
\hline Anomodon viticulosus (Fig. 7a) & 24 & $0.5-4$ \\
\hline Antitrichia curtipendula & 1 & 0.8 \\
\hline Brachythecium cf. rutabulum & 1 & 2 \\
\hline Brachythecium cf. velutinum & 5 & $1-2$ \\
\hline Brachytheciaceae indet. & 139 & $1-2$ \\
\hline Eurhynchium hians & 3 & $1-2$ \\
\hline Eurhynchium praelongum & 5 & $1-2$ \\
\hline Eurhynchium striatum & 1 & 2 \\
\hline Homalia trichomanoides & 2 & $1-2$ \\
\hline Homalothecium sericeum (Fig. 7b) & 8 & $0.5-2$ \\
\hline Hypnum cupressiforme & 1 & 1 \\
\hline Neckera complanata (Fig. 7d) & 31 & $0.5-4$ \\
\hline Neckera crispa (Fig. 7c) & 76 & $0.5-4$ \\
\hline Neckera pennata & 1 & 1 \\
\hline Neckera cf. pumila & 2 & $0.5-2$ \\
\hline Neckeraceae indet. & 15 & 1 \\
\hline Rhynchostegium riparioides & 3 & $1-2$ \\
\hline Sanionia uncinata (Drepanocladus $u$.) & 1 & 1.5 \\
\hline Thamnobryum alopecurum (Fig. 7e) & 48 & $0.5-5$ \\
\hline Thuidium tamariscinum (Fig. 7f) & 34 & $0.5-3$ \\
\hline
\end{tabular}

Moss fragments from fractions 2, 3 and 4

single larval chamber allow them to be identified unambiguously as asexual generation galls formed by a member of the gall wasp genus Andricus. More specifically, the fossils are identical in external structure and the suspension of the larval chamber to those induced by the asexual generation of the present-day southeast European species A. hungaricus (= Cynips hungarica). No similar species exists, and it is probable that the fossils represent Eemian members of the A. hungaricus lineage. The galls of this species, which grow from buds on the previous year's shoots of Quercus robur (Mayr 1907; Buhr 1965; Melika et al. 2000), are among the largest in the western Palaearctic, and are extremely tough and woody. The galls mature in autumn and fall to the ground with the oak leaves. The adult wasps emerge in the spring, and this species is exceptional in that the adult wasps can remain in the gall for up to 8 years (Stone et al. 2002, and unpublished data). This survival strategy is associated with galls that are very resistant to decay, and which therefore would seem good candidates for fossilisation. Fraction 2 yielded two, as yet unidentified gall structures (Table 2), one of which might be a fragment of an Andricus hungaricus gall, while the other represents an aggregation of larval chambers (Fig. 4k).

Well-preserved fossil galls are rare (Larew 1992) and so far, Eemian galls were completely unknown. All galls
Table 4 Plants from the Kreftenheye Formation at Raalte (Eemian, The Netherlands)

\begin{tabular}{|c|c|c|c|c|c|}
\hline & \multicolumn{2}{|c|}{$\begin{array}{l}\text { Clay on } \\
\text { gall }\end{array}$} & \multicolumn{2}{|c|}{$\begin{array}{l}\text { Piece of } \\
\text { clay }\end{array}$} & \multirow{2}{*}{$\begin{array}{l}\text { Van } \\
\text { Geel } \\
\text { et al. } \\
\%\end{array}$} \\
\hline & $n$ & $\%$ & $n$ & $\%$ & \\
\hline \multicolumn{6}{|l|}{$\Sigma$ pollen taxa } \\
\hline Abies (Fig. 8a) & 9 & 1.8 & 2 & 0.4 & ca. 1 \\
\hline Acer & 2 & 0.4 & 2 & 0.4 & - \\
\hline Alnus (Fig. 8b) & 118 & 23.2 & 137 & 24.7 & 21 \\
\hline Betula (Fig. 8c) & 10 & 2.0 & 8 & 1.4 & ca. 2 \\
\hline Buxus & - & - & 2 & 0.4 & - \\
\hline Carpinus (Fig. 8d) & 109 & 21.4 & 63 & 11.3 & 24 \\
\hline Corylus (Fig. 8e) & 74 & 14.6 & 153 & 27.5 & 24 \\
\hline Fraxinus & 3 & 0.6 & 3 & 0.5 & ca. 2 \\
\hline Ilex & 3 & 0.6 & 3 & 0.5 & - \\
\hline Picea & 47 & 9.3 & 14 & 2.5 & 18 \\
\hline Pinus (Fig. 8f) & 55 & 10.9 & 36 & 6.5 & ca. 2 \\
\hline Quercus (Fig. 8g) & 43 & 8.5 & 100 & 17.9 & 2.5 \\
\hline Salix & 12 & 2.4 & 14 & 2.4 & - \\
\hline Taxus & - & - & - & - & ca. 1 \\
\hline Tilia & 2 & 0.4 & 2 & 0.4 & ca. 2 \\
\hline Ulmus (Fig. 8h) & 20 & 3.9 & 18 & 3.3 & ca. 0.5 \\
\hline & 507 & 100 & 557 & 100 & 100 \\
\hline
\end{tabular}

\section{Other taxa}

\begin{tabular}{|c|c|}
\hline Alisma & - \\
\hline Amaranthaceae (Chenopodiaceae) & - \\
\hline Apiaceae & 1 \\
\hline Artemisia & - \\
\hline Asteraceae (Liguliflorae) & - \\
\hline Caltha type & - \\
\hline Caryophyllaceae & 1 \\
\hline Cyperaceae & 9 \\
\hline Diporotheca (Type 143) & 1 \\
\hline Ericales & 3 \\
\hline Hedera & 4 \\
\hline Linum (large) & - \\
\hline monolete psilate spores (Fig. 8i) & 56 \\
\hline Mougeotia (Type 61) & - \\
\hline Myriophyllum verticillatum & - \\
\hline Nuphar & 1 \\
\hline Nymphaea & 1 \\
\hline perforation plates (Alnus type) & 8 \\
\hline Persicaria maculosa type & - \\
\hline Poaceae & 36 \\
\hline Polypodium & - \\
\hline Ranunculus & 1 \\
\hline Rumex acetosella & - \\
\hline Salvinia (microspores) & 1 \\
\hline Sparganium emersum type & 17 \\
\hline Sparganium erectum type & 7 \\
\hline
\end{tabular}


Table 4 continued

\begin{tabular}{|c|c|c|c|c|c|}
\hline & \multicolumn{2}{|c|}{$\begin{array}{l}\text { Clay on } \\
\text { gall }\end{array}$} & \multicolumn{2}{|c|}{$\begin{array}{l}\text { Piece of } \\
\text { clay }\end{array}$} & \multirow{2}{*}{$\begin{array}{l}\text { Van } \\
\text { Geel } \\
\text { et al. } \\
\%\end{array}$} \\
\hline & $n$ & $\%$ & $n$ & $\%$ & \\
\hline Spirogyra (Type 132) & - & & 1 & & \\
\hline trilete psilate spores & 2 & & 1 & & \\
\hline Typha latifolia & 2 & & 2 & & \\
\hline Urtica & - & & 1 & & \\
\hline Viscum & - & & 1 & & \\
\hline not identified & 10 & & 7 & & \\
\hline Lycopodium (added) & 512 & & 37 & & \\
\hline
\end{tabular}

Pollen samples ( $\Sigma$ pollen taxa compared with Van Geel et al. (1986), Fig. 3, level $20.5 \mathrm{~m}$ ). The macrofossil remains from the pollen samples are included in Table $2(*)$

described here, including community, ecological and evolutionary aspects, will be dealt with in more detail by G. N. Stone et al., (in preparation).

Wood, jet and amber

Wood occurs in large quantities at the Hooge Broek site (Fig. 2b, c), mostly as pieces smaller than $30 \mathrm{~cm}$. Altogether, 92 pieces from fractions 1 and 2 were identified (Table 1). The origin of the assemblage is heterogeneous. Elements such as Abies, Acer, Alnus, Betula, Fraxinus, Picea, Pinus, Populus, Quercus and Salix, of which also pollen (except Populus) and macrofossils (except Fraxinus) were found, might be Eemian. However, Celtis, Chamaecyparis and Pterocarya almost certainly originate from an earlier interglacial. The last records of Celtis (pollen) and Pterocarya (pollen and macrofossil) in The Netherlands are from the Holsteinian (Zagwijn 1973, 1978), while the last occurrence of Chamaecyparis in western and central Europe was in the Tiglian (Lang 1994). Regarding the preservation of the wood (soft, light or hard, heavy), only (a part of) the material of Alnus, Fraxinus, Picea, Quercus and Salix might be of Eemian age (wood soft and light), while the rest (Table 1) is probably older (Early Pleistocene or Neogene; wood hard and heavy). Relatively high percentages of reworked material in fossil wood assemblages, compared to assemblages of seeds etc., might be due to differences in taphonomic characteristics of these categories. For instance, seeds and fruits hydrate sooner than wood from the same source, and become deposited together with waterlogged reworked wood rather than with the floating contemporary wood. This might explain why no Carpinus wood was found at Hooge Broek.

Wood has been recorded from several other Pleistocene sites in the area. The wood from pits near Oldenzaal (Van der Burgh 1961) and Schoonlo (Huisman 1977), mainly from conifers, was also found to be of mixed origin and age (Pleistocene and older). Three pieces of wood (Picea, Pinus) from a pit near Zwolle were dated as Early Weichselian (Stapert 1985). The wood (not identified) found by Van Uum (2003) in another pit near Zwolle was considered to date from a warm phase in the Quaternary.

Jet ("black amber"), a hard black bituminous variety of lignite, was found abundantly at Hooge Broek, mostly as pieces $<2 \mathrm{~cm}$ (Fig. 4c). Few pieces are larger (Fig. 4b), up to $43 \mathrm{~mm}$. The material is diverse, including shiny amorphous pieces, but also more lignitic pieces. It was probably reworked from an older (Early Pleistocene?), ice-pushed deposit into the Zutphen clay and/or the under/overlying post-Saalian sands and gravels, washed from the matrix in the sorting process and, by its similar specific gravity, deposited in the waste together with all other plant remains. This might be true also for the amber $(n=2)$ found at Hooge Broek (Fig. 4a).

Van Uum (2003) also reported jet (many pieces) and amber $(n>100)$. The amber was thought to originate from the Appelscha Formation, a Cromerian (ca. 850,000475,000 years ago) eastern fluviatile deposit, while the origin of the jet was considered unknown. In contrast to the amber and jet from Hooge Broek, it was probably directly dredged from a buried ice-pushed ridge.

Seeds, fruits, cones, spines, leaf fragments, bud scales and stem fragments

These remains (Tables 1,2), as the pollen and spores also do (see below), predominantly reflect Eemian forest and fresh water vegetations. Several palynomorph taxa were not found in the macrofossil material (Fraxinus, Hedera, Ulmus). Common trees and shrubs are Acer (Fig. 5a), Alnus (Fig. 5b), Buxus sempervirens (Fig. 5m), Carpinus betulus (Fig. 5c), Cornus sanguinea (Fig. 5i), Picea (Fig. 4e), Quercus (Fig. 4j) and Rubus fruticosus, of which Alnus and Carpinus are dominant. Less common are $\mathrm{Cra}$ taegus monogyna, Clematis vitalba (Fig. 5d), Cornus mas (Fig. 5g, h), Corylus avellana (Fig. 4i), Ilex aquifolium (Fig. 5e), Populus, Prunus cf. spinosa, Rhamnus frangula (Fig. 5f), Salix, Sambucus, Taxus baccata and Tilia. Fresh water elements include taxa such as Brasenia schreberi, Ceratophyllum demersum, Hippuris vulgaris, Hydrocharis morsus-ranae, Lemna, Najas flexilis, N. marina, N. minor, Nuphar lutea, Nymphaea alba, Nymphoides peltata, Potamogeton spp., Ranunculus (aquatilis type), Salvinia natans (abundant), Stratiotes aloides (Fig. 51), Trapa natans (abundant; Fig. 4l-q) and Zannichellia palustris. Further, many riparian elements, such as Alisma, Iris pseudacorus, Oenanthe aquatica, Sagittaria sagittifolia, Schoenoplectus lacustris (abundant; Fig. 5k), Sparganium spp., Typha, and weeds from drier places, such as Chenopodium spp., 
Fig. 3 Asexual galls of the gall wasp Andricus hungaricus from the Eemian of the Hooge Broek sand/gravel pit. a Entire galls (attachment scars at the bottom), showing their exterior marked with regularly spaced bumps; b Gall sectioned lengthwise (attachment area at the bottom), showing the central airspace in which a larval chamber was situated; c Gall cross-sectioned, illustrating the compressed state of the galls and the airspace containing a single larval chamber in the upper half. $\mathrm{Bar}=1 \mathrm{~cm}$
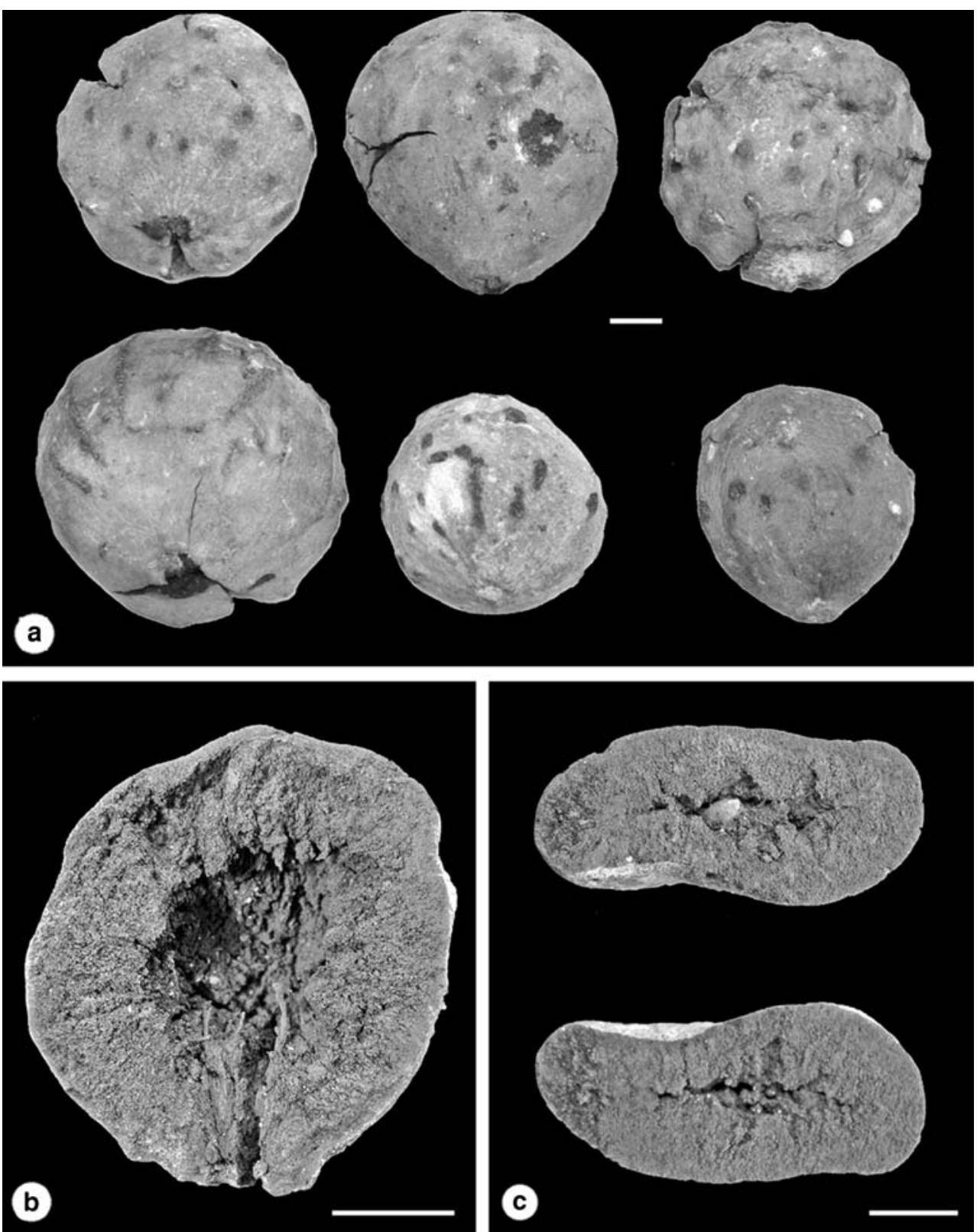

Persicaria spp., Plantago major, Ranunculus spp., Rumex maritimus (abundant; Fig. 5j), Echinochloa crus-galli (Fig. 6b) and Urtica spp., are present.

Of particular note are some species that are common in the Eemian of Hooge Broek, but which do not occur in the present flora of The Netherlands. The water fern Salvinia natans is known from several Eemian localities in the IJssel valley (see "Introduction"). Nowadays, it is a rare and transient species in northwest Europe (Meusel et al. 1965; Jalas and Suominen 1988; Wolff and Schwarzer 2005). Trapa natans (water chestnut), has been reported from the Holsteinian of Neede (Florschütz 1957) and Uitwellingerga (Zagwijn 1978). So far, this species has not been known from the Eemian of the Netherlands (see also
Van der Vlerk and Florschütz 1950, p 154). The use of Trapa fruits in prehistoric times, as well as the presence of Trapa during recent centuries in The Netherlands has been well documented (Bakels and Zeiler 2005; Weeda 1980, p. 28), but at present this central European plant (Meusel et al. 1978) is absent from the Dutch flora (Van der Meijden 2005). The central and south European Buxus sempervirens, Staphylea pinnata (Fig. 5n) and Vitis sylvestris (Fig. 5o) were also elements of the Eemian flora of the Hooge Broek area. Nowadays, these species are introduced and locally naturalised in The Netherlands (Van der Meijden 2005).

Some species listed in Tables 1 and 2 certainly did not belong to the Eemian flora of The Netherlands. A single 
Fig. 4 Amber, jet, conifer cones, fragments of fruits and seeds, and a gall structure from the Eemian of the Hooge Broek sand/gravel pit. a Amber (fraction 2); b Jet (fraction 2); c Jet (fraction 3); d Pinus sylvestris cone (fraction 1); e Picea abies cone (fraction 1); f Stratiotes

kaltennordheimensis, fragment (fraction 3; probably reworked); g Magnolia cor (fraction 2; probably reworked); h Juglans tephrodes endocarp (fraction 1; probably reworked); i Corylus avellana (fraction 2); $\mathbf{j}$ Quercus sp. cupules (fraction 2); k Unidentified gall structure, showing an aggregation of larval chambers (fraction 2); 1, o Trapa natans fruit in threedimensional preservation (fraction 2); m, p Trapa natans fruit dorso-ventrally compressed (fraction 2); n, q Trapa natans fruit (small specimen) laterally compressed (fraction 2). Bar $=1 \mathrm{~mm}(\mathbf{f}, \mathbf{g}), 5 \mathrm{~mm}$ $(\mathbf{k}, \mathbf{p}, \mathbf{q})$ or $1 \mathrm{~cm}(\mathbf{a}-\mathbf{e}, \mathbf{h}-\mathbf{j}, \mathbf{l}-\mathbf{o})$
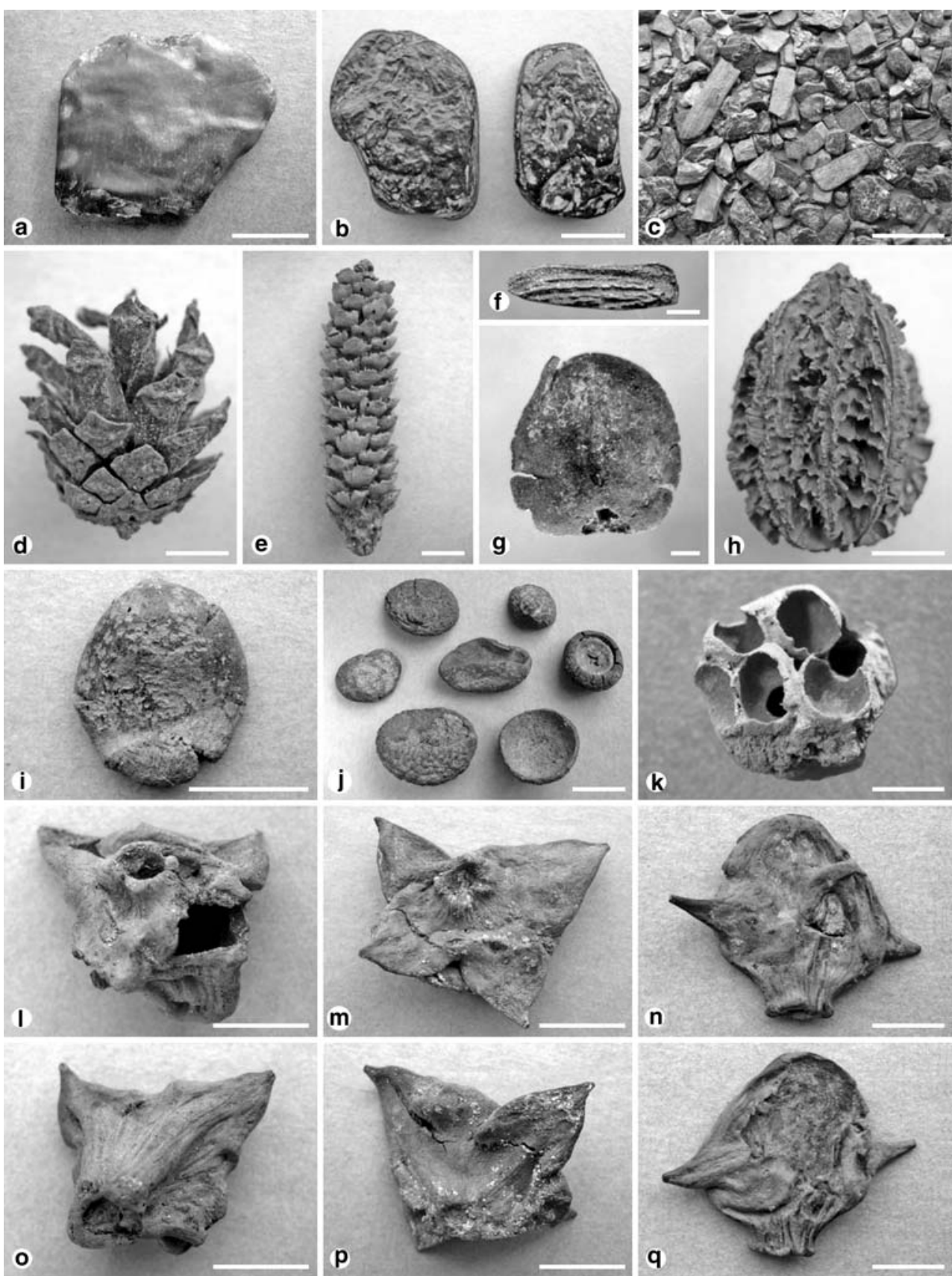

endocarp of Juglans bergomensis was found at Hooge Broek (Fig. 4h). This is closely related to the extant $J$. cinerea from eastern North America (Manchester 1987, sub J. tephrodes); both belong to Juglans sect. Cardiocaryon (butternuts), which disappeared from Europe after the Waalian (ca. 1.5-1.2 million years ago) (Manchester 1987; Lang 1994). Many endocarps of J. bergomensis were found in the Haerst suction-dredging pit near Zwolle. Probably they were dredged directly from a Tiglian (ca. 2.45-1.8 million years ago) deposit present in a buried icepushed ridge (Van Uum 2003; Hamming 2003). Magnolia (Fig. 4g) disappeared from Europe after the Tiglian (Lang
1994). The specimens of Stratiotes kaltennordheimensis (Fig. 4f) are preserved as jet. They may have been reworked during the Eemian from a Miocene (ca. 235.3 million years ago) deposit present in a nearby icepushed ridge.

\section{Bryophytes}

The bryophyte sample (from fractions 2, 3 and 4) contained 456 stem and branch fragments, of which 401 could be identified (Table 3). The fragments are $0.5-5 \mathrm{~cm}$ long. Only gametophytes of mosses and no liverworts are 
Fig. 5 (Fragments of) fruits and seeds, cones and a leaf fragment from the Eemian of the Hooge Broek sand/gravel pit. a Acer sp. (spp.?) fruits without wing (fraction 3);

b Alnus sp. cones (fraction 3); c Carpinus betulus (fraction 3); d Clematis vitalba (fraction 3); e Ilex aquifolium (fraction 3); f Rhamnus frangula (fraction 3); g Cornus mas (fraction 2); h Cornus mas, fragments (fraction 3); i Cornus sanguinea (fraction 3); $\mathbf{j}$ Rumex maritimus perianth fragments (fraction 3); k Schoenoplectus lacustris (fraction 3); I Stratiotes aloides (fraction 3); m Buxus sempervirens leaf fragment (fraction 3); n Staphylea pinnata (fraction 2); o Vitis sylvestris (fraction 3); p Xanthium cf. strumarium (fraction 3). Bar $=1 \mathrm{~mm}$ $(\mathbf{m}, \mathbf{o}, \mathbf{p}), 5 \mathrm{~mm}(\mathbf{f}, \mathbf{n})$ or $1 \mathrm{~cm}$ (a-e, $\mathbf{g}-\mathbf{l})$
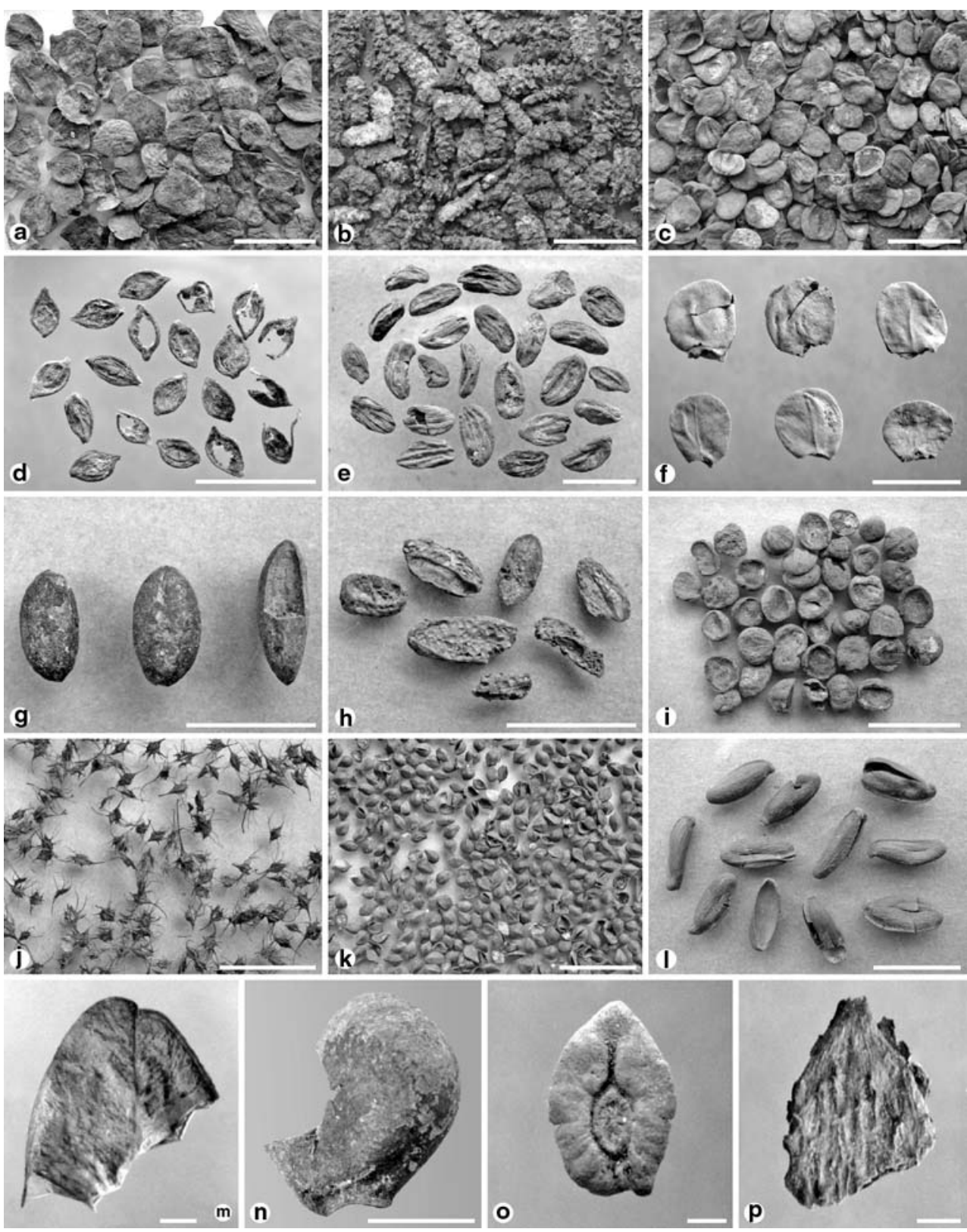
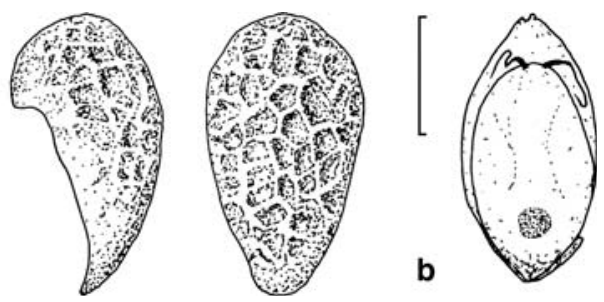

Fig. 6 Seed and fruit from the Eemian of the Hooge Broek sand/ gravel pit. a Ajuga cf. genevensis (fraction 3); b Echinochloa crusgalli (fraction 4$)$. Bar $=1 \mathrm{~mm}$

represented. Although fragmented, most specimens are well-preserved, bearing intact leaves and sometimes even such tiny structures as paraphyllia. No direct evidence was found as to the substrate onto which the mosses were attached. The material was studied using a microscope and compared with descriptions, illustrations and herbarium material of recent Dutch mosses (Landwehr 1984; Touw and Rubers 1989). Neckera pennata, not known from The Netherlands, was compared with the description provided by Smith (2004) and with material from Poland.

Neckera crispa (Fig. 7c) and Thamnobryum alopecurum (Fig. 7e) are the most frequently found moss species. Remarkably, the commonest species in our sample, $\mathrm{Nec}$ kera crispa, known from the Eemian and many subfossil records since then (Kuijper 2000), is currently extremely rare in The Netherlands (Touw and Rubers 1989). Further common species are Anomodon viticulosus (Fig. 7a), 


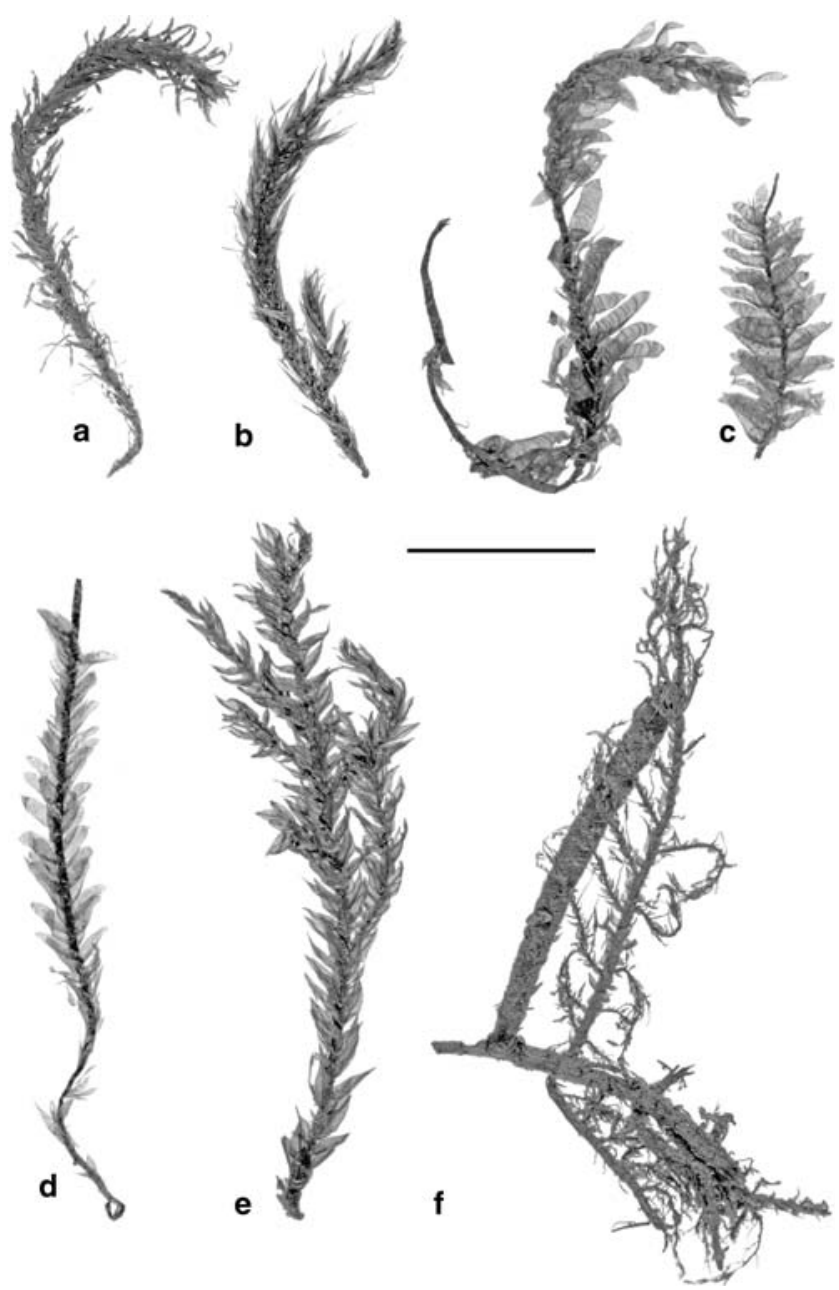

Fig. 7 Bryophytes from the Eemian of the Hooge Broek sand/gravel pit (photos Ben Kieft). a Anomodon viticulosus; b Homalothecium sericeum; c Neckera crispa; d Neckera complanata; e Thamnobryum alopecurum; f Thuidium tamariscinum. Bar $=5 \mathrm{~mm}$

Homalothecium sericeum (Fig. 7b), Neckera complanata (Fig. 7d) and Thuidium tamariscinum (Fig. 7f). Twelve other species have been identified, although in small quantities (Table 3). Most fragments of Brachytheciaceae (Brachythecium, Eurhynchium, Homalothecium, Rhynchostegium) could not be identified to species or genus level, which is usual in this family. These results are consistent with the notion that the bryofloras of the Pleistocene interglacials and that of the Holocene in Europe are very much the same (Dickson 1973; Birks 1982).

Most mosses from Hooge Broek might be characterised as woodland species. Most of the common species, except Anomodon viticulosus, also have been found in the nearby Eemian site of Kamphuis (Van Geel et al. 1986). This site and the Eemian site of Oerel, Germany (Behre et al. 2005) yielded various mosses that might have grown in or close to water (Amblystegium, Calliergon, Calliergonella, Campylium elodes, Drepanocladus, Tomenthypnum nitens,
Scorpidium), but the Hooge Broek sample does not contain any hydrophytic species, which is in contrast to the macrofossil remains and palynomorphs. Moss assemblages with affinity to our sample from Hooge Broek were recorded from the Eemian of Ejstrup, Denmark (Hartz 1909) and Wretton, England (Dickson 1973). Species recorded from all three sites are Anomodon viticulosus, Antitrichia curtipendula, Eurhynchium hians (as E. swartzii), E. striatum, Homalothecium sericeum and Neckera complanata. All common species from Hooge Broek were also recorded from Wretton (Anomodon viticulosus, Homalothecium sericeum, Neckera complanata, N. crispa, Thamnobryum alopecurum, Thuidium tamariscinum).

Pollen, spores and other palynomorphs

The palynomorphs from the $0.5 \mathrm{~cm}^{3}$ sample of clay adhering to one of the oak galls were partly strongly corroded, while those from the $1 \mathrm{~cm}^{3}$ sample from the centre of a piece of clay were found excellently preserved. As in the study by Van Geel et al. (1986), which provides detailed data of the nearby Late Eemian locality Kamphuis near Denekamp, the total of tree and shrub pollen ( $\Sigma$ pollen) was used for percentage calculations (Table 4). The most important $\Sigma$ pollen taxa are Alnus (Fig. 8b), Carpinus (Fig. 8d), Corylus (Fig. 8e), Picea, Pinus (Fig. 8f) and Quercus (Fig. 8g). Minor elements are Abies (Fig. 8a), Betula (Fig. 8c), Salix and Ulmus (Fig. 8h), while Acer, Fraxinus, Ilex and Tilia occur in percentages $<1 \%$. Within the pertinent post-Saalian context, the high percentages of Carpinus pollen are strongly indicative of the Eemian. Similar values are known only from the Bavalian (ca. 1.10.85 million years ago), even up to $60 \%$ in the Bavel interglacial (Zagwijn and De Jong 1984).

On the basis of the high Carpinus values and the absence of Taxus, both pollen spectra may be placed in the Late Eemian E5 pollen zone according to the subdivision by Zagwijn (1961, 1996). Comparing with the data presented by Van Geel et al. (1986), the Hooge Broek spectra agree most with their level $20.5 \mathrm{~m}$ spectrum, which is in the upper part (E5b) of the E5 zone. The largest deviations concern our values of Picea (9.2 and 2.5 vs. 18\%), Pinus (10.8 and 6.5 vs. ca. $2 \%$ ) and Quercus (8.4 and 17.9 vs. $2.5 \%)$.

Both Hooge Broek spectra especially reflect the Late Eemian forest flora, including the above mentioned trees and shrubs, and taxa such as Hedera and Viscum. Further, relatively high percentages of monolete psilate spores (Fig. 8i), Poaceae, Cyperaceae and Sparganium are present. Besides Sparganium, several other riparian and fresh water elements, such as Alisma, Myriophyllum, Nuphar, Nymphaea, Spirogyra and Typha, are represented, mostly as single grains. Microspores of Salvinia were also found, 
Fig. 8 Scanning electron micrographs of palynomorphs and sporangia from the Eemian of the Hooge Broek sand/gravel pit. a Abies pollen; b Alnus pollen; c Betula pollen; d Carpinus pollen; e Corylus pollen; f Pinus pollen; g Quercus pollen; h Ulmus pollen; i monolete psilate spore; j Mega- (e) and microsporangia (i) of Salvinia natans, and other objects washed from clay found in fraction 2; $\mathbf{k}$

Microsporangium of Salvinia natans (fraction 2); $\mathbf{l}$

Megaporangium of Salvinia natans (fraction 2); $\mathbf{m}$ Microsporangium of Salvinia natans (fraction 2), showing microspores through gaps in the sporangium wall. $\mathrm{Bar}=5 \mu \mathrm{m}$ $(\mathbf{b}, \mathbf{c}, \mathbf{g}, \mathbf{h}), 10 \mu \mathrm{m}(\mathbf{a}, \mathbf{d}-\mathbf{f}, \mathbf{i})$ $50 \mu \mathrm{m}(\mathbf{k}, \mathbf{m}), 100 \mu \mathrm{m}(\mathbf{l})$ or $0.5 \mathrm{~mm}(\mathbf{j})$
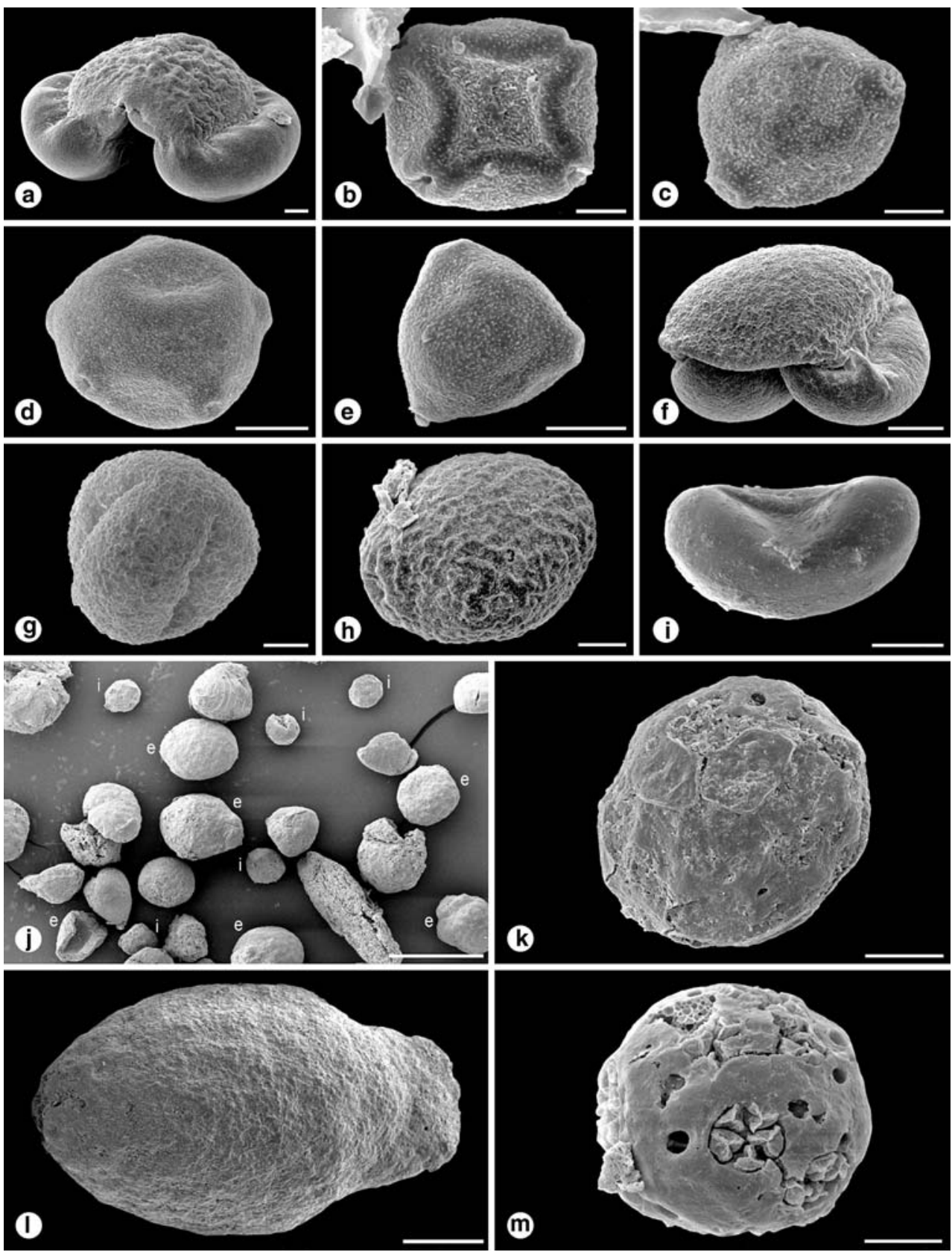

but the abundant microsporangia in the clay still held their contents (Fig. 8j, k, m). Microspores of Salvinia do not disperse, but germinate through the sporangium wall.

The macrofossil remains from the pollen samples are indicated in Table 2.

\section{Discussion}

Environment of Andricus hungaricus

The asexual generation of the oak gall wasp Andricus hungaricus is entirely committed to Quercus robur.
Although the Quercus remains from Hooge Broek (wood, fruits, leaf fragments, pollen) could not be identified to species level, $Q$. robur is considered to have been widely available. The most direct evidence for the environment of A. hungaricus is the pollen spectrum of the clay from one of the galls (Table 4). The other spectrum ("piece of clay") is very similar, and both are consistent with the macrofossils and the wood, though these may have a wider stratigraphical range (see below). Together, the pollen spectra indicate forest vegetations on the one hand and riparian and freshwater communities on the other. Such a mixture might be very well matched with the environment of the Hooge Broek area in the Eemian IJssel valley. 
Opportunities for both water and riparian plants were provided by the lower parts of the valley, while the forest species might have been growing in the higher parts or on the ice-pushed ridges bordering the valley. Plant remains, including the galls, would have gathered in the lower parts, where they became embedded in a clayey deposit (Burck's clay-peat bed, Salvinia bed, Zutphen Member of Kreftenheye Formation). Quercus robur may have been a member of a type of forest with much Carpinus in the dryer parts or with much Alnus in the wetter parts of the area. The mosses provide evidence for the existence in or near the valley of forest (not necessarily strictly coeval) with large deciduous broad-leaved trees, also known as "ancient woodland' (Porley and Hodgetts 2005). For instance, Thamnobryum alopecurum and Thuidium tamariscinum may have grown on the tree bases and also on the ground under the trees. Anomodon viticulosus, Homalothecium sericeum and the Neckera species occur especially on trunks of broad-leaved trees, on which they may occur up to several metres high, being strongly attached to the bark and covering considerable surfaces. For Neckera crispa we checked the labels of the collections in the Nationaal Herbarium, Leiden, and found that a broad spectrum of deciduous host trees is mentioned: Fagus, Quercus and Fraxinus in The Netherlands, and Fagus, Quercus, Fraxinus, Acer, Sambucus, Carpinus, Populus, Ulmus and Liriodendron in other west European localities. However, the available data are not sufficient to provide evidence whether the oaks bearing the Andricus hungaricus galls were indeed growing in such 'ancient woodland' as mentioned above, or in the wetter, Alnus-rich parts.

\section{Stratigraphic boundaries of Burck's clay-peat bed}

The five groups of plant remains described above make up the flora of Burck's clay-peat bed (Salvinia bed, Zutphen Member of Kreftenheye Formation) in the Hooge Broek area. Except for part of the wood and some other reworked elements, they are mutually consistent sets, palynologically dated as Late Eemian. The palynomorphs indicate zone E5b, but only two samples have been analysed. Therefore, the stratigraphic range of the macrofossils might be larger. For instance, Taxus pollen is absent, but several Taxus leaf fragments and one seed were found, which is indicative of zones E4b and E5a. Furthermore, the occurrence of Trapa suggests that part of zones E3 and E4a, including the Eemian thermal maximum, is also represented (Coope 2000). On the basis of a pollen analysis, Van der Vlerk and Florschütz (1950) placed the base of the clay-peat bed at Zwartewater (see "Introduction") in the Corylus zone (E4), just above the level with the highest Corylus values. The top of the clay-peat bed in the Zwartewater diagram reaches into the Early Weichselian (see also Zagwijn 1961;
Stapert 1985; De Mulder et al. 2003). Burck (1949) demonstrated the irregular morphology of the layer (more or less continuous, up to $17 \mathrm{~m}$ thick), which is probably due to regional differences in deposition and/or erosion. Therefore, only a detailed pollen analysis may determine the stratigraphical range of the clay-peat bed in the Hooge Broek area.

\section{Thermophilous elements}

Several thermophilous water plants occur in the Hooge Broek material. Salvinia natans is abundantly present. This water fern requires water temperatures of $14-17^{\circ} \mathrm{C}$ for germination (Wolff and Schwarzer 2005). Brasenia schreberi, Najas minor and Trapa natans may also be classified as thermophilous (see also Aalbersberg and Litt 1998; Bińka and Nitychoruk 2003). Trapa needs several months of water temperatures over $20^{\circ} \mathrm{C}$ for fruiting (Meusel et al. 1978). Although Trapa is common in the macrofossils spectrum, no pollen was found in the clay samples analysed. This might indicate that it does not occur throughout the clay-peat bed (see also above). Trapa natans has been found together with Najas minor and Salvinia natans in several Eemian sites in England (Godwin 1975; Coope 2000). From the same localities, hippopotamus and straight-tusked elephant are known, but the stratigraphic relation to the botanical remains is unclear (Franks 1960; West 1968). At present, Trapa and Hippopotamus amphibius occur together in several places in Africa. A report from the Aquatic Rapid Assessment Program in Botswana's Okavango Delta (Montambault 2000) includes the remark that the extremely sharp barbs of Trapa fruits stick into the feet of the hippos, by means of which the plant is spread. Mention is made also of the invasive species Salvinia molesta, which would thrive due to the eutrophication by hippo excrements and thus expel the native flora, including Trapa (Bingham 2000; Safran 2000). It would be interesting to know whether the hippopotamus and straight-tusked elephant remains from Hooge Broek originate from a Trapa- and/or Salvinia-rich part of Burck's clay-peat bed. Trapa natans, Najas minor, Salvinia natans and several other plants found at Hooge Broek still occur together in Europe in, for instance, the river Danube and its delta (Radescu 1967; Oťaheľová and Valachovič 2002).

The above mentioned fresh water thermophiles are paralleled in the terrestrial vegetation of the Eemian Hooge Broek area by Buxus sempervirens (Zagwijn 1996; Aalbersberg and Litt 1998), which is present in one of the pollen samples (E5b) and common among the macrofossils, and Cornus mas (Bińka and Nitychoruk 2003). According to Zagwijn (1996), Buxus sempervirens spread over The Netherlands, Germany and Poland during the first 
part (E5a) of the Carpinus phase, and later (E5b) also to Denmark, requiring mean July temperatures of $17^{\circ} \mathrm{C}$ or more. The presence of galls of the southeast European oak gall wasp Andricus hungaricus (Buhr 1965) also indicates relatively high temperatures during the Carpinus phase.

The Eemian summer thermal maximum probably occurred during the early-temperate substage, that is, zone E4a (Turner 2000; see also Zagwijn 1996; Aalbersberg and Litt 1998; Coope 2000). Possibly, the Trapa remains originate from this zone, but the Andricus hungaricus galls are clearly later, being placed by the adhering palynomorphs in zone E5b. This underpins the notion by Turner (2000) of different organisms having different optima. Further, the presence of a taxon in a certain area is not necessarily determined by climate alone. With regard to A. hungaricus, the availability of Quercus cerris, the probable host of the sexual generation of the gall wasp (Cook et al. 2002), may also be considered an important factor. So far, the characteristic "hairy" cupules of $Q$. cerris have not been found among our material, but the Turkey oak may have been rare in the area or present only at a considerable distance from it. Nowadays, $Q$. cerris is widely present in northwest Europe, having been introduced and naturalised, which explains the expansion over the area of the oak gall wasp species $A n$ dricus kollari, A. corruptrix, A. lignicola and A. quercuscalicis. These species complete their life cycle in the same hosts as A. hungaricus. More recent examples of such invaders are Andricus aries, A. grossulariae and A. lucidus, while yet others, including A. hungaricus, may follow (Stone et al. 2002).

\section{Humans}

Many of the prominent elements mentioned above for Hooge Broek (Alnus, Carpinus, Najas spp., Quercus, Rumex maritimus, Salvinia, Stratiotes aloides, Trapa, Hippopotamus, Palaeoloxodon antiquus) were listed by Parfitt et al. (2005) as being present in the Cromer Forest bed landscape at Pakefield, UK, during an interglacial in the early part of the Cromerian Complex (ca. 700,000 years ago). This bed also provided the earliest evidence of human activity in northern Europe. The Eemian IJssel valley might have offered comparable circumstances, similarly suited for inhabitation by humans. Some of the flint artefacts found at the Hooge Broek site are consistent with those made by Neanderthals, who probably roamed through the area at that time (Schlüter 2006). Unfortunately, their stratigraphic context is unknown, as is often the case with Middle Palaeolithic artefacts from The Netherlands (Roebroeks 2005).

Acknowledgments We would like to thank the REKO Grondverzet en Wegenbouw bedrijf Raalte B.V. for permission to collect material and use the samples from a boring at the Hooge Broek pit, Peter Jellema (Netherlands Institute of Applied Geoscience TNO-NITG, Utrecht) for his help in finding stratigraphical data from the Hooge Broek area and Wim Westerhoff (Netherlands Institute of Applied Geoscience TNO-NITG, Utrecht) for interpreting this information. George Melika (Systematic Parasitoid Laboratory, Köszeg, Hungary) is acknowledged for confirming the identification of the Andricus hungaricus galls, providing recent specimens for comparison and referring the first author to the gall specialist among us (GNS). Hans van der Plicht (Centrum voor Isotopen Onderzoek, Groningen) took care of radiocarbon dating one of the fossil galls. Bas van Geel (Institute for Biodiversity and Ecosystem Dynamics, Universiteit van Amsterdam) assisted in identifying the grass stem fragments. Bas van Geel and Otto Brinkkemper (Rijksdienst voor Archeologie, Cultuurlandschap en Monumenten, Amersfoort) provided valuable comments on the manuscript. Cris Hesse (Nationaal Herbarium Nederland) is thanked for supporting the study of the bryophytes, Ben Kieft (Nationaal Herbarium Nederland) for the photos of the bryophytes and Bertie Joan van Heuven (Nationaal Herbarium Nederland) for assisting in the scanning electron microscopy. Ben Kieft skillfully arranged all photos into clear and attractive plates. The first two authors dedicate this study to Professor Corrie Bakels (Faculteit der Archeologie, Universiteit Leiden), with thanks for prolonged teaching and cooperation.

\section{References}

Aalbersberg G, Litt T (1998) Multiproxy climate reconstructions for the Eemian and Early Weichselian. J Q Sci 13:367-390

Bakels C, Zeiler J (2005) De vruchten van het land. De neolithische voedselvoorziening / The fruits of the land. Neolithic subsistence. In: Louwe Kooijmans LP, van den Broeke PW, Fokkens $\mathrm{H}$, van Gijn $\mathrm{AL}$ (eds) Nederland in de prehistorie / The prehistory of The Netherlands. Bert Bakker/Amsterdam University Press, Amsterdam, pp 311-335

Behre KE, Hölzer A, Lemdahl G (2005) Botanical macro-remains and insects from the Eemian and Weichselian site of Oerel (northwest Germany) and their evidence for the history of climate. Veg Hist Archaeobot 14:31-53

Bingham M (2000) Land use changes on the floodplains of the upper Zambezi in western Zambia. In: Timberlake J (ed) Biodiversity of the Zambesi Basin wetlands 3. Biodiversity Foundation Africa, Occasional Publications in Biodiversity 8, pp 1-18

Bińka K, Nitychoruk J (2003) The Late Saalian, Eemian and Early Vistulian pollen sequence at Dziewule, eastern Poland. Geol Q 47:155-168

Birks HJB (1982) Quaternary bryophyte palaeo-ecology. In: Smith AJE (ed) Bryophyte ecology. Chapman \& Hill, London, pp 473490

Bosch JHA, Cleveringa P, Meijer T (2000) The Eemian stage in the Netherlands: history, character and new research. Neth J Geosci 79:135-145

Bosscha Erdbrink DP (2002) Fossiele resten van haas en bever uit Salland [Fossils of hare and beaver from Salland]. Cranium 19:156-159

Bosscha Erdbrink DP (2003) De vondst van een stuk hoektand van een nijlpaard [The find of a piece of a canine of a hippopotamus]. Cranium 20:3-5

Bosscha Erdbrink DP, Brewer JG, Mol D (2001) Some remarkable Weichselian elephant remains. Deinsea 8:21-26

Buhr H (1965) Bestimmungstabellen der Gallen (Zoo- und Phytocecidien) an Pflanzen Mittel- und Nordeuropas. Fischer, Jena

Burck HDM (1949) Continentale Eemlagen in het dal van den Gelderschen IJssel, benevens opmerkingen betreffende het 
IJssellaagterras [Continental Eemian deposits in the valley of the River Gelderse IJssel]. Verh Koninklijk Nederlands GeologischMijnbouwkundig Genootschap Geol Ser 15:32-43

Cleveringa P, Meijer T, van Leeuwen RJW, de Wolf H, Pouwer R, Lissenberg T, Burger AW (2000) The Eemian stratotype locality at Amersfoort in the central Netherlands: a re-evaluation of old and new data. Neth J Geosci 79:197-216

Cook JM, Rokas A, Pagel M, Stone GN (2002) Evolutionary shifts between host oak sections and host-plant organs in Andricus gallwasps. Evolution 56:1821-1830

Coope GR (2000) The climatic significance of coleopteran assemblages from the Eemian deposits in southern England. Neth J Geosci 79:257-267

De Mulder FJ, Geluk MC, Ritsema IL, Westerhoff WE, Wong TE (2003) De ondergrond van Nederland [The subsoil of The Netherlands]. Wolters-Noordhoff Groningen

Dickson JH (1973) Bryophytes of the Pleistocene. The British record and its chorological and ecological implications. University Press, Cambridge

Eshuis HJ (1946) Palynologisch en stratigrafisch onderzoek van de Peelvenen [Palynological and stratigraphical study of the Peelvenen]. Thesis. Universiteit Utrecht

Florschütz F (1930) Fossiele overblijfselen van de plantengroei tijdens het Würmglaciaal en het Riss-Würminterglaciaal in Nederland [Remains of the vegetation during the Würm glacial and the Riss/Würm interglacial in The Netherlands]. Proc Koninklijke Akad Wet 33:1043-1044

Florschütz F (1934) Palaeobotanisch onderzoek van jongpleistocene afzettingen in het oosten van Overijssel [Palaeobotanical study of Late Pleistocene deposits in the east of Overijssel]. Proc Koninklijke Akad Wet 37:297-301

Florschütz F (1935) Über die Flora in den Niederlanden während der letzten Eiszeit. Proc Sixth Int Bot Cong Amst 1:205-208

Florschütz F (1957) The subdivisions of the Middle and Young Pleistocene up to the Late-glacial in The Netherlands, England and Germany, mainly based on the results of paleobotanical investigations. Geol Mijnbouw Nieuwe Ser 19:245-249

Florschütz F, Anker-van Someren AHM (1956) Het Jong-Kwartair op de Peelhorst en in de westelijk van de Horst gelegen Grote Slenk, de palynologische resultaten [The Late Quaternary of the Peelhorst and the Grote Slenk west of the Horst. Palynological results]. Meded Geol Sticht 10:55-65

Franks JW (1960) Interglacial deposits at Trafalger Square, London. New Phytol 59:145-152

Godwin H (1975) History of the British flora. A factual basis for phytogeography. 2nd edn. Cambridge University Press, Cambridge

Hamming C (2003) De stuwwal onder Zwolle [The ice-pushed ridge under Zwolle]. Grondboor Hamer 57:113-115

Hartz N (1909) Interglacial gytjeaflejring ved Ejstrup [Interglacial deposit at Ejstrup]. In: Hartz N (ed) Bidrag til Danmarks tertiaere og diluviale flora. Danmarks geologiske Undersøgelse 2(20):205-231, 286

Huisman H (1977) Over het voorkomen van bruinkoolhout en barnsteen in de ondergrond van Noord-Nederland en NoordDuitsland [On the occurence of lignite and amber in the subsoil of the northern Netherlands and northern Germany]. Grondboor Hamer 31:154-160

Jalas J, Suominen J (1988) Atlas Florae Europaeae 1. University Press, Cambridge

Jong J de (1955) Geologische onderzoekingen in de stuwwallen van oostelijk Nederland [Geological investigations in the ice-pushed ridges of eastern Netherlands]. Meded Geol Sticht Nieuwe Ser $8: 33-58$

Kerkhoff NC (1993) Zoogdier- en schildpadfossielen [Mammal and tortoise fossils]. In: Rappol M (ed) In de bodem van Salland en Twente. Lingua Terrae, Amsterdam, pp 101-120
Kuijper WJ (2000) The former occurrence of Neckera crispa Hedw. in the Netherlands. Lindbergia 25:28-32

Landwehr J (1984) Nieuwe atlas Nederlandse bladmossen [New atlas of Dutch mosses]. Natuurhistorische bibliotheek 38. Koninklijke Nederlandse Natuurhistorische Vereniging Utrecht, Thieme Zutphen

Lang G (1994) Quartäre Vegetationsgeschichte Europas. Fischer, Jena

Larew HG (1992) Fossil galls. In: Shorthouse JD, Rohfritsch O (eds) Biology of insect-induced galls. University Press, Oxford, pp 50-59

Manchester SR (1987) The fossil history of the Juglandaceae. Monogr Syst Bot Mo Bot Gard 21

Mayr GL (1907) Die mittel-europäischen Eichen-Gallen in Wort und Bild. Junk, Berlin

Melika G, Csóka G, Pujade-Villar J (2000) Check-list of oak gall wasps of Hungary, with some taxonomic notes (Hymenoptera: Cynipidae, Cynipinae, Cynipini). Ann Hist Nat Mus Nat Hung 92:265-296

Meusel H, Jäger E, Weinert E (1965) Vergleichende Chorologie der zentraleuropäischen Flora 1. Fischer, Jena

Meusel H, Jäger E, Rauschert S, Weinert E (1978) Vergleichende Chorologie der zentraleuropäischen Flora 2. Fischer, Jena

Mol D (1993) Nijlpaarden dobberden in de IJssel [Hippos floated in the River IJssel]. Grondboor Hamer 47:73-78

Mol D (1994) Nog meer nijlpaarden uit Nederlandse bodem [More hippos from the Dutch soil]. Grondboor Hamer 48:7-8

Mol D, van den Bergh GD, de Vos J (1999) Fossil proboscideans from The Netherlands, the North Sea and the Oosterschelde Estuary. Deinsea 6:119-146

Montambault JR (2000) Expedition Okavango. Aquatic Rapid Assessment Program in Botswana's Okavango Delta, species June 11, 2000. http://www.investigate.conservation.org/expeditions/okavango/dispatch/20000611/species.htm

Oťaheľová H, Valachovič M (2002) Effects of the Gabčikovo hydroeclectric-station on the aquatic vegetation of the Danube river (Slovakia). Preslia 74:323-331

Parfitt SA, Barendregt RW, Breda M, Candy I, Collins MJ, Coope GR, Durbidge P, Field MH, Lee JR, Lister AM, Mutch R, Penkman KEH, Preece RC, Rose J, Stringer CB, Symmons R, Whittaker JE, Wymer JJ, Stuart AJ (2005) The earliest record of human activity in northern Europe. Nature 438:1008-1012

Porley R, Hodgetts N (2005) Mosses and liverworts. The New Naturalist Library 97. Collins, London

Radescu L (1967) Das Donaudelta. In: Liepolt R (ed) Limnologie der Donau. Eine monographische Darstellung 3. Schweizerbart, Stuttgart, pp 295-315

Roebroeks W (2005) De Neanderthaler en zijn voorgangers. Oud- en midden-paleolithicum / Neanderthals and their predecessors. Lower and Middle Palaeolithic. In: Louwe Kooijmans LP, Broeke PW van den, Fokkens H, van Gijn AL (eds) Nederland in de prehistorie / The prehistory of The Netherlands. Bert Bakker. Amsterdam University Press, Amsterdam, pp 93-113

Safran S (2000) Expedition Okavango. Aquatic Rapid Assessment Program in Botswana's Okavango Delta, issues June 15, 2000. The delta's tiny troublemaker. http://www.investigate.conservation.org/expeditions/okavango/dispatch/20000615/issues.htm

Schlüter D (2006) Neanderthalers in Overijssel en het Graafschap Bentheim [Neanderthals in Overijssel and Graafschap Bentheim]. Grondboor Hamer 60:66-72

Shackleton NJ, Sánchez-Goñi MF, Pailler D, Lancelot Y (2003) Marine Isotope Substage 5e and the Eemian interglacial. Glob Planet Change 36:151-155

Smith AJE (2004) The moss flora of Britain and Ireland. University Press, Cambridge

Stapert D (1985) Oud hout uit een zuigkolk bij Zwolle [Ancient wood from a suction-dredging pit near Zwolle]. Grondboor Hamer 39:130-141 
Stone GN, Cook JM (1998) The structure of cynipid oak galls: patterns in the evolution of an extended phenotype. Proc R Soc Ser B 265: 979-988

Stone GN, Schönrogge K, Atkinson RJ, Bellido D, Pujade-Villar J (2002) The population biology of oak gallwasps (Hymenoptera: Cynipidae). Annu Rev Entomol 47:633-668

Touw A, Rubers WV (1989) De Nederlandse bladmossen [The Dutch mosses]. Natuurhistorische bibliotheek 50. Koninklijke Nederlandse Natuurhistorische Vereniging Utrecht

Turner C (2000) The Eemian interglacial in the North European plain and adjacent areas. Neth J Geosci 79:217-231

Uum R van (2003) Zandwinning 'Haerst' bij Zwolle, een vreemde eend in het rivierengebied [Sand pit 'Haerst' near Zwolle, a strange element in the river area]. Grondboor Hamer 57:101-112

Van der Burgh J (1961) De ouderdom van de grindafzetting in de groeve Slebos (Oldenzaal O: Twente) [The age of the gravel deposit in the Slebos pit (Oldenzaal, Overijssel: Twente)]. Grondboor Hamer 5de reeks:205-215

Van Geel B, Klink AG, Pals JP, Wiegers J (1986) An upper Eemian lake deposit from Twente, eastern Netherlands. Rev Palaeobot Palynol 47:31-61

Van Geel B, Pals JP, Reenen GBA van, Huissteden J van (1995) The indicator value of fossil fungal remains, illustrated by the palaeoecological record of a Late Eemian/Early Weichselian deposit in the Netherlands. Meded Rijks Geol Dienst 52:297316

Van den Hoek Ostende L, de Vos J, Leloux J (2002) De Rijn als vindplaats van fossiele zoogdieren [The Rhine as a locality for finding fossil mammals]. Grondboor Hamer 56:77-81

Van Leeuwen RJW, Beets DJ, Bosch JHA, Burger AW, Cleveringa P, van Harten D, Herngreen GFW, Kruk RW, Langereis CG, Meijer T, Pouwer R, de Wolf $H$ (2000) Stratigraphy and integrated facies analysis of the Saalian and Eemian sediments in the Amsterdam-Terminal borehole, the Netherlands. Neth J Geosci 79:161-196
Van der Meijden R (2005) Heukels' flora van Nederland. WoltersNoordhoff Groningen

Van der Vlerk IM, Florschütz F (1950) Nederland in het ijstijdvak [The Netherlands during the Ice Age]. De Haan Utrecht

Vermeer-Louman GG (1934) Pollen-analytisch onderzoek van den West-Nederlandschen bodem [Pollen analytical study of the subsoil in western Netherlands]. Thesis. Universiteit Amsterdam

Weeda EJ (1980) On the reliability of older literature concerning the Netherlands flora $( \pm 1550- \pm 1850)$. In: Mennema J, QuenéBoterenbrood AJ, Plate CL (eds) Atlas of the Netherlands flora, vol 1. Extinct and very rare species. Junk, The Hague, pp 26-29

West RG (1968) Pleistocene geology and biology, with especial reference to the British Isles. Longmans, London

Wolff P, Schwarzer A (2005). Der Schwimmfarn Salvinia natans (L.) All. (Salviniaceae) in der Pfalz. Pollichia 91:83-96

Zagwijn WH (1961) Vegetation, climate and radiocarbon datings in the Late Pleistocene of the Netherlands. Part 1: Eemian and Early Weichselian. Mededelingen Geologische Stichting. Nieuwe Ser 14:15-45

Zagwijn WH (1973) Pollenanalytic studies of Holsteinian and Saalian Beds in The Northern Netherlands. Meded Geolo Sticht Nieuwe Ser 24:139-156

Zagwijn WH (1975) Indeling van het Kwartair op grond van veranderingen in vegetatie en klimaat [Subdivition of the Quaternary on the basis of changes in vegetation and climate]. In: Zagwijn WH, van Staalduinen CJ (eds) Toelichting bij geologische overzichtskaarten van Nederland. Rijks Geologische Dienst, Haarlem, pp 109-114

Zagwijn WH (1978) A macroflora of Holsteinian age from the northern part of The Netherlands. Rev Palaeobot Palynol 26:243-248

Zagwijn WH (1996) An analysis of Eemian climate in Western and Central Europe. Q Sci Rev 15:451-469

Zagwijn WH, de Jong J (1984) Die Interglaziale von Bavel und Leerdam und ihre stratigraphische Stellung im niederländischen Früh-Pleistozän. Meded Rijks Geol Dienst 37:155-169 